\title{
Optimization, Sensitivity and Energy Management of a PV/Wind/Battery and PV/Wind/Supercapacitor Hybrid Renewable Energy System for the Climatic Conditions of Haldia using HOMER: A Case Study
}

\author{
M. Das ${ }^{1, *}$, R. Mandal ${ }^{2, \dagger}$ \\ ${ }^{1}$ AEIE Department, Haldia Institute of Technology, Haldia, India \\ 2 School of Energy Studies, Jadavpur University, Kolkata, India
}

(Received 10 January 2021; revised manuscript received 15 June 2021; published online 25 June 2021)

\begin{abstract}
The demand for hybrid renewable energy systems (HRES) is growing nowadays for serving different types of loads. PV and Wind energy resources are complementary. HRES using PV and wind energy sources may increase system reliability for serving a load throughout a year. This paper analyses the cost, feasibility, and reliability of two types of HRES using HOMER software for Haldia, namely, PV/Wind/Battery and PV/Wind/Supercapacitor. These systems are cost-optimized using the net present cost (NPC) of the system and cost of the energy (COE) of the system. The solar radiation, wind speed, the temperature of the site, hourly load, and unit cost of the components of the HRES are given input to the HOMER software. The feasibility of the system is studied for the lowest cost of energy (COE) with different ratios of electricity production from PV and wind energy systems. The reliability of the system is measured in terms of the percentage of the unmet load. It is found that 80:20 and 73:27 share of PV and wind energy production is optimum for PV/Wind/Battery and PV/Wind/ Supercapacitor system respectively for the climatic conditions of Haldia, India. The technical parameter sensitivity and cost sensitivity analysis and the energy management of the system are also reported in this paper. The study revealed that the HRES using supercapacitor can deliver peak load, during the day and night, as compared to a battery. It also depicts that supercapacitor can charge very fast with low values of available solar or wind energy than that of the battery.
\end{abstract}

Keywords: PV, Wind, Battery, Supercapacitor, Hybrid, HOMER.

DOI: 10.21272/jnep.13(3).03011

PACS numbers: 89.30.Ee, 82.47.Uv

\section{INTRODUCTION}

Investigation on different types of $100 \%$ hybrid renewable energy systems have been done for remote area power generation and household applications [1,2]. Renewable energies are intermittent, especially, solar and wind energy. To overcome the intermittency of the individual energy sources, hybrid energy generations are considered. Wind and solar energy systems are more popular hybrid energy generation due to their daily and seasonal complementary nature. In India, solar energy is available for 300 days whereas wind energy is available mainly in coastal regions and during the period from April to September. Hybrid energy utilization may be feasible in small-scale energy production. Many studies have been done on hybrid energy systems. $6 \mathrm{~kW}$ Solar PV and wind hybrid system feasibility analysis is studied using RET-Screen and HOMER software for household applications, $11.27 \mathrm{kWh} /$ day demand with peak power demand of $2.39 \mathrm{~kW}$, in Northern Cyprus. It aims to fulfill the monthly demand and to sell and store the excess generated power [3]. The effects of PV panel sizing, wind turbine sizing, and battery bank capacity have been studied for a standalone PV/wind/battery system for a remote island using HOMER software [4]. The results conclude that $84 \%$ and $16 \%$ of PV array and wind turbine share the power generation respectively. $\mathrm{PV} /$ wind renewable energy systems are also tested with different energy storage devices [5]. PV/Wind/Battery [68], PV/Wind/Fuel Cell [9, 10], PV/Wind/pumped hydro systems [11] have been reported. Another energy storage technology supercapacitor (SC), due to its high cost and less energy density is still less studied using PV/Wind energy systems [12]. However, it has many advantages over battery storage. It has high cycle life, high power density, and low maintenance requirement compared to batteries. These features have been exploited in PV/wind energy systems to make the system more reliable. Wind turbine generators are coupled with supercapacitors to mitigate the fluctuations of WTGS in the distribution network [13]. Wind/PEM fuel cell/alkaline electrolyzer, a battery, and a supercapacitor bank is used for optimal configuration using total annual cost and loss of power supply [14]. Supercapacitors/Battery energy storage system is used for active power management in a winddiesel system [15]. Supercapacitors are used to give short-term buffering to wind fluctuations and intermittency in wind-powered reverse osmosis membrane systems [16]. SC/battery optimal sizing is done for smoothing wind power [17]. Based on the literature review and the research gap discussed above, the objective of this paper is to examine the techno-economic performance of an off-grid PV/Wind/Battery and PV/Wind/SC HRES using HOMER software to fulfill a typical agricultural load and compare the energy management of the systems especially during the rainy season when the PV energy is intermittent in availability and to study the sensitivity towards the cost of the different components of the system. In this paper, optimum PV and wind energy share are to be found out for the above-mentioned

\footnotetext{
*madhumita666@gmail.com

$\dagger$ ratan_mandal99@yahoo.co.in

The results were presented at the International Conference on Innovative Research in Renewable Energy Technologies (IRRET-2021)
} 
HRES. This research work analyses the impact of the wind energy penetration and storage autonomy on the systems, on the number of energy storage devices, the cost of energy (COE), net present cost (NPC) of the system. The electricity production from $\mathrm{PV}$ and wind are chosen with different ratios and the best utilization of the renewable and energy storage system are ensured considering $10 \%$ capacity shortage. The sensitivity analysis and the energy management of the system are also done at the climatic conditions of Haldia.

\section{METHODOLOGY AND SYSTEM DESIGN}

The PV/Wind/Battery and PV/Wind/SC HRES are analyzed using HOMER (Fig. 1). The two types of HRES PV/ Wind/ Battery and PV/Wind/SC are optimized considering the following inputs in HOMER: the wind speed, solar radiation and temperature data of the site, load characteristics, and cost of the components. The following economic parameters are evaluated for the system evaluation: the Net Present Cost (NPC) of the system, Cost of Energy (COE), initial investment, and operational and maintenance cost. The minimal NPC system and COE with the different ratios of energy production from PV and wind based on the above criteria are chosen as the system for the given load followed by the sensitivity and energy management analysis in the subsequent sections. The minimum solar radiation is received in the rainy season, from June to September, and the clearness index is obtained the lowest in July in Haldia, India. The maximum wind speed is obtained from April to September.

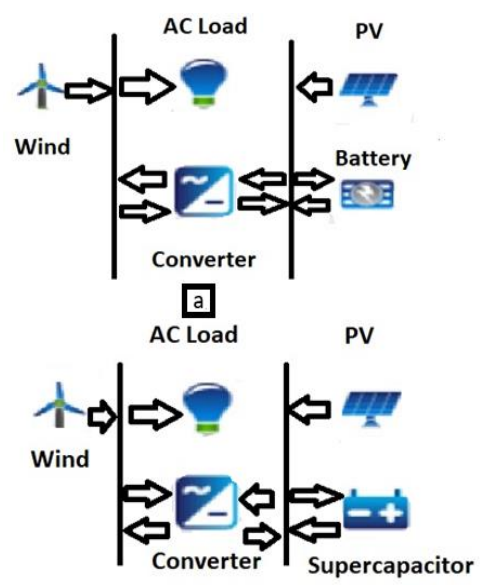

b

Fig. 1-The schematic of HRES for the agricultural load analyzed in HOMER: (a) PV/Wind/Battery and (b) PV/Wind/ Supercapacitor

\section{LOAD CHARACTERISTICS}

PV/Wind/Battery and PV/Wind/SC off-grid hybrid systems are designed to fulfill the need of the agricultural load of a typical agricultural farm at Haldia, West Bengal, India. The daily agricultural load profile is generated. The typical total power of the load is $6.619 \mathrm{~kW}$ with $48.048 \mathrm{k} \mathrm{Wh}$ /day of energy consumption by calculating the hourly load profile of a day (Fig. 2).

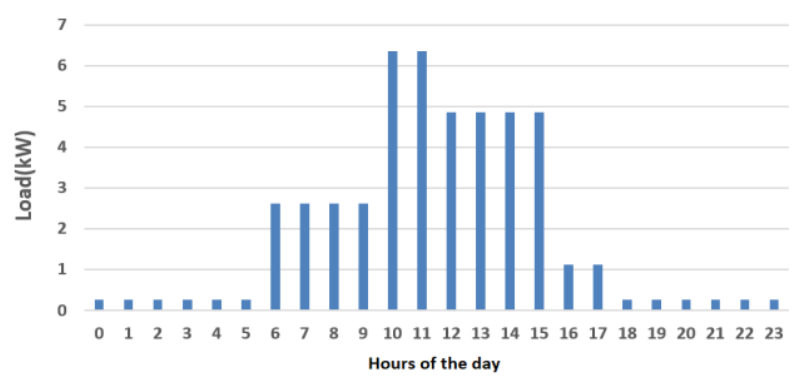

Fig. 2 - The daily agricultural load profile

\section{SYSTEM COMPONENTS SIZING}

The basic sizing of the components of a PV/Wind/ battery and PV/Wind/SC system is PV modules, Wind turbine, battery, supercapacitor, and converter which are discussed in this section. In this research work, the solar modules have been used in combination with wind turbine generators to meet the load requirement throughout the year. The PV modules are of polycrystalline silicon are of polycrystalline silicon types with a maximum rated power of $1 \mathrm{~kW}$ with a lifetime of 25 years. To fulfill the energy needs during the night and rainy season wind energy generator is considered. Wind energy is mostly available for six months, from April to September, in India. During the rainy season period, wind energy generators can be an alternative to solar energy generation. The unit wind turbine considered in this study is $1 \mathrm{~kW}$. The main utilization of the battery is to serve the load at night when the PV and wind energy is not available. The unit capacity of the lead-acid battery considered for the design of the systems in HOMER software is $1 \mathrm{kWh}$. The supercapacitor known as a double-layer capacitor is used to enhance the system lifetime, deliver high peak power. The supercapacitor of nominal voltage $3 \mathrm{~V}$. For a bus voltage of $12 \mathrm{~V}$, the string size of 4 supercapacitors is chosen with the minimum state charge of $20 \%$. The cost of a 3000F Generic supercapacitor is $58 \$$. The converter efficiency is considered as $90 \%$ with the initial capital cost as $200 \$$.

\section{RESULTS AND DISCUSSION}

The optimization, sensitivity analysis, and energy management of the PV/Wind/Battery and PV/Wind/SC system are presented in this section.

\subsection{Optimization}

Optimization of energy sources plays a vital role in the process of the decision-making of good energy management and cost management strategies. The optimization of $\mathrm{PV} / \mathrm{Wind} /$ Battery and $\mathrm{PV} / \mathrm{Wind} / \mathrm{SC}$ system is based on the $10 \%$ capacity shortage which is presented in this section.

\subsubsection{PV/Wind/Battery System}

The minimum battery size obtained at $10 \%$ of wind energy penetration indicates minimum COE per $\mathrm{kWhr}$ generation (Fig. 3a). However, at $20 \%$ of wind energy penetration, the battery capacity obtained is $78 \mathrm{kWhr}$. The unmet load of the system and is observed two 
points of undershoots at $10 \%$ and $20 \%$ of wind energy share (Fig. 3b). The difference in COE at these two points is nominal and hence a system with a $20 \%$ wind energy share can be chosen to make the system more beneficial considering the constraints of the PV systems in the rainy season months as the solar radiation from June to September remains low which is within the range of $4-4.5 \mathrm{kWhr} / \mathrm{m}^{2} /$ day. The effect of the wind energy penetration on the $\mathrm{COE}$ of the system is studied (Fig. 3c). The COE of the system remains constant from the wind energy penetration range of $15-30 \%$.
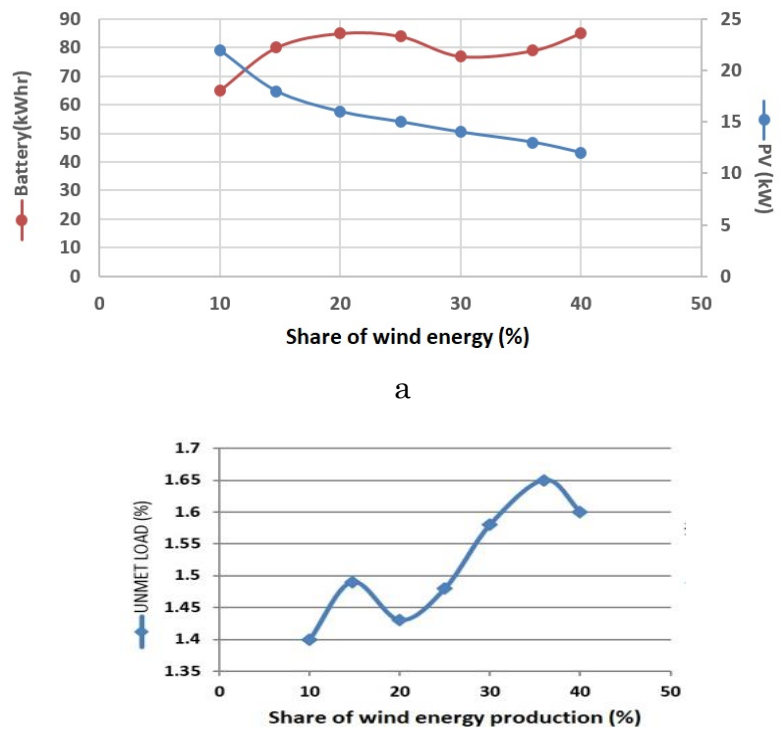

$\mathrm{b}$

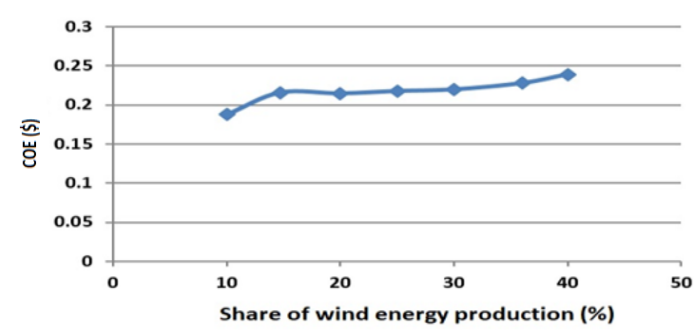

c

Fig. 3 - (a) Optimized PV/Wind/Battery systems, (b) Unmet load, (c) COE for a different share of wind energy production

\subsubsection{PV/Wind/ SC System}

The drawback of the PV/Wind/Battery system is that its response is not fast to the change in supplying the load. The supercapacitor is a very fast charging and discharging storage device. The $\mathrm{PV} / \mathrm{Wind} / \mathrm{SC}$ system is studied for the climatic conditions of Haldia. The system is optimized with a different share of wind energy (Fig. 4a). The optimization of the PV/Wind /SC system is done using HOMER software for different shares of $\mathrm{PV}$ and Wind energy. The system is optimized with the various shares of wind energy. It can be depicted that for an $8 \%, 10 \%$, and $27 \%$ share of the wind energy production, the no. of supercapacitors required are less. It is observed that the unmet load and the range of COE are also less for the share of $8 \%, 10 \%$, and $27 \%$ of wind energy (Fig. $4 \mathrm{~b}, \mathrm{c}$ ). So, to support the system during the rainy season $27 \%$ of the wind energy share system is chosen to serve the agricultural load.
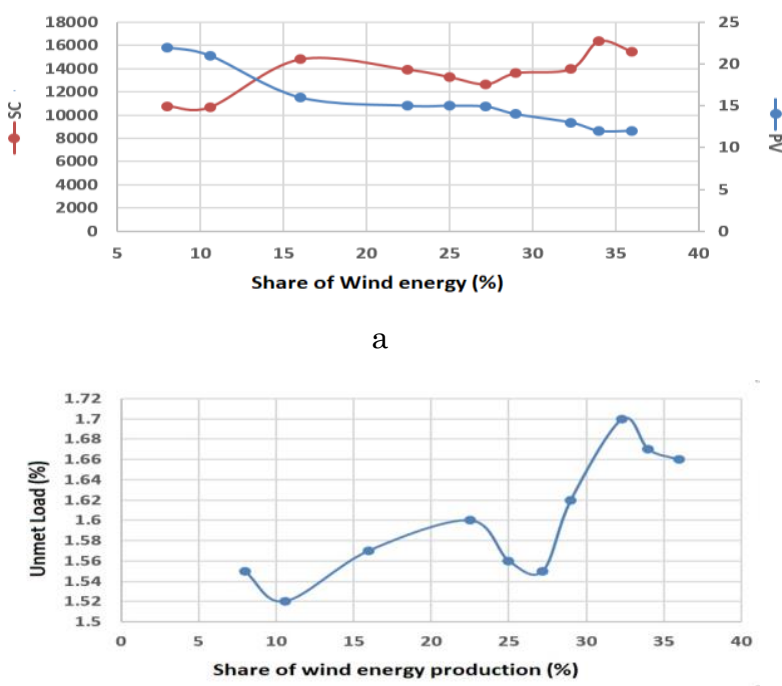

$\mathrm{b}$

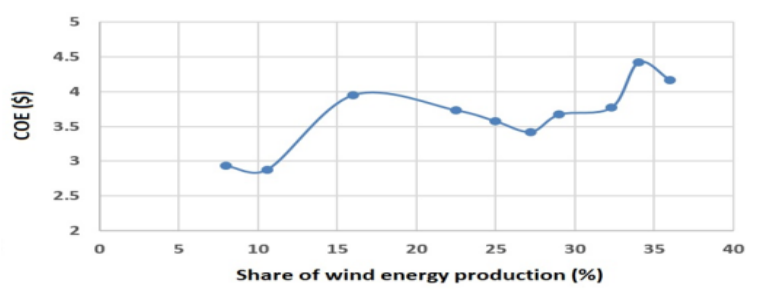

C

Fig. 4 - PV/Wind/ SC system: (a) Optimization, (b) Unmet load, (c) $\mathrm{COE}$

\subsection{Sensitivity Analysis of PV/Wind/Battery and PV/Wind/SC Systems}

The sensitivity analysis is done to two different types of parameter changes: Technical parameters of the system and sensitivity of the system to the future cost of the different components on the system. The sensitivity of the tilt angle and the temperature of the panel are studied as the technical parameters whereas futuristic parameters such as the future cost of the solar PV panel, battery cost, wind turbine cost, and supercapacitor cost are studied. The PV production is found to be maximum at $19668 \mathrm{kWh} / \mathrm{yr}$. for the tilt angle of $24^{\circ}$ which is $2^{\circ}$ more than the latitude angle. The sensitivity to the PV operating cell temperature from $30^{\circ} \mathrm{C}$ to $45^{\circ} \mathrm{C}$ by $5{ }^{\circ} \mathrm{C}$ is found that with the increase of the temperature of the panel by $5{ }^{\circ} \mathrm{C}$, the PV production rate decreases by $1.8-1.9 \%$. The sensitivity of the system towards the cost of different components of the systems is also studied which can be beneficial for predicting the future COE of the systems (Table 1).

Table 1 - System cost sensitivity

\begin{tabular}{|l|l|l|}
\hline No. & Components & COE Equation \\
\hline 1. & PV cost & $y=0.00007 x+0.2769$ \\
\hline 2. & Wind turbine cost & $y=0.00003 x+0.1629$ \\
\hline 3. & Battery cost & $y=0.0004 x+0.1819$ \\
\hline 4. & Supercapacitor cost & $y=0.0085 x+0.1576$ \\
\hline
\end{tabular}




\subsection{Energy Balance of the PV/Wind/Battery and PV/Wind/SC Systems}

To assess the system operation, the details of the power flow between the different energy sources of the two HRES are analyzed for the rainy season months when the solar radiation is available intermittently, i.e., from July to October (Fig. 5). The total electrical load serves, unmet electrical load, PV power output, and wind power output, and battery state of charge of the system are studied. From this study, it is found that the PV/Wind/Battery system can serve the load to
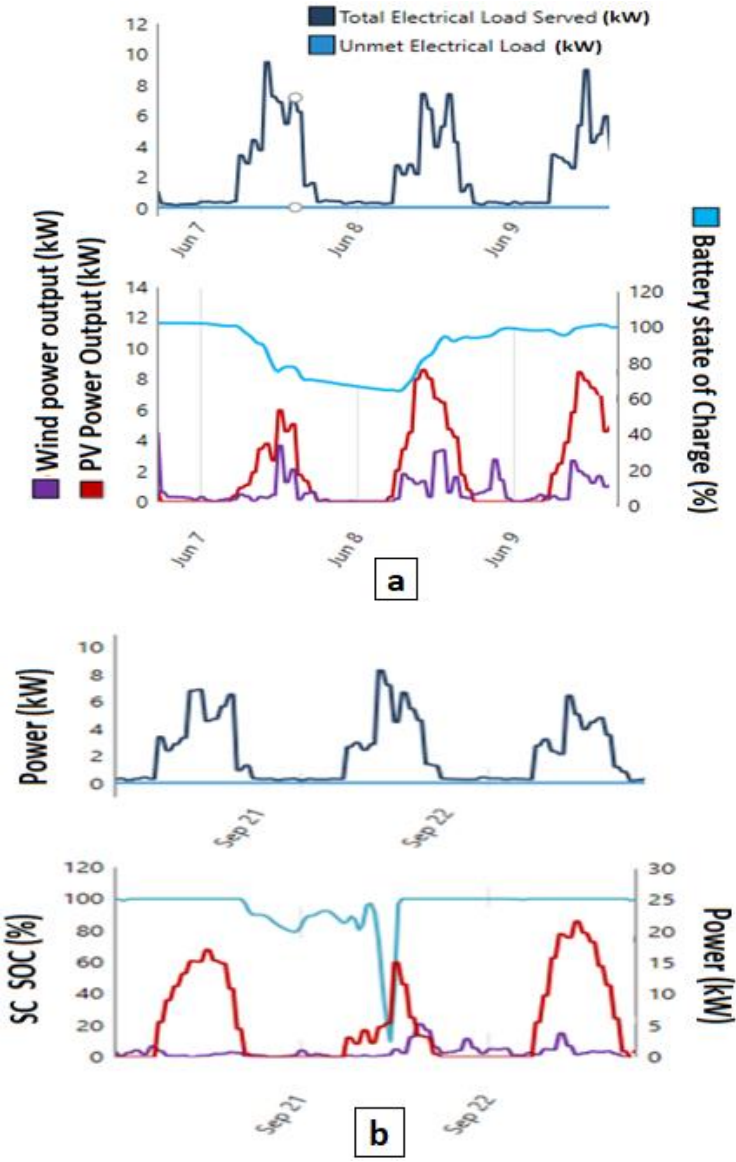

Fig. 5 - Energy management of (a), PV/Wind/Battery and (b) $\mathrm{PV} / \mathrm{Wind} / \mathrm{SC}$ system for low radiation months

\section{REFERENCES}

1. R. Rawat, S.S. Chandel, Int. J. Renew. Energy Res. 3 No 3, 595 (2013).

2. P.K. Katti, Energy Procedia 14, 2081 (2012).

3. F. Al-Turjman, Z. Qadir, M. Abujubbeh, C. Batunlu, Comput. Electr. Eng. 86, 106743 (2020).

4. T. Ma, H. Yang, L. Lu, Appl. Energy 121, 149 (2014).

5. M.D. Al-Falahi, S.D.G. Jayasinghe, H.J.E.C. Enshaei, Energy Convers. Manag. 143, 252 (2017).

6. S. Sanajaoba, E. Fernandez, Renew. Energy 96, 1 (2016).

7. A. Ahadi, S-K. Kang, J-H. Lee, Appl. Energy 170, 101 (2016).

8. M. Fadaeenejad, MAM. Radzi, MZA AbKadir, H. Hizam, Renew. Sustain. Energy Rev. 30, 299 (2014).

9. A. Maleki, A. Askarzadeh, Int. J. Hydrogen Energy 39, 9973 (2014). maintain the very low unmet load. The battery SOC decreases to $65 \%$ when both PV and wind energy is not available and to $80-90 \%$ when either PV or wind energy is available. However, the battery has slow charging and discharging characteristics. The supercapacitor SOC remains $100 \%$ when no energy is utilized from it to supply the load whereas when the solar radiation and the wind energy is not sufficient enough to fulfill the load demand during the day, the load is powered by the supercapacitor and hence there is no unmet load. The SC has discharged up to $20 \%$ SOC. When the PV energy and wind energy are available, the SC is charged to $100 \%$. This design helps to meet the requirements to supply power for the peak load in the rainy season.

\section{CONCLUSIONS}

This paper presents the effect of penetration of wind energy system on PV/Wind/Battery system and $\mathrm{PV} / \mathrm{Wind} / \mathrm{SC}$ system in an off-grid configuration to meet a typical agricultural load at Haldia, India. The effect of different ratios of PV/Wind electricity contribution on the techno-economic evaluation of the two systems is assessed using HOMER software. It is found that 80:20 and 73:27 share of the PV/wind energy generation is optimum for PV/ Wind/battery and PV/Wind/SC system respectively. The optimum tilt angle is found to be $24^{\circ}$ which is $2^{\circ}$ more than the latitude of the site. The sensitivity analysis of the PV module temperature showed that with the increase of the panel temperature by $5{ }^{\circ} \mathrm{C}$, the PV production rate decreases by $1.8-1.9 \%$. A module cooling or a temperature control system is recommended for the climatic conditions of Haldia. The $\mathrm{PV}$, wind, and battery cost sensitivity on PV/Wind/ Battery system and SC cost sensitivity on PV/Wind/SC system are evaluated to predict future COE of the system. The cost sensitivity of the $\mathrm{SC}$ in the $\mathrm{PV} / \mathrm{Wind} / \mathrm{SC}$ showed that a reduction of the SC cost may make it at par with the battery-based system. The energy management of the two systems shows that PV/Wind/SC system can serve peak loads better. It showed that the supercapacitor can deliver peak load, load during the day, and also load during the night. It also depicts that it can charge very fast with low values of available solar or wind energy. Also, a PV/Wind/SC system with low hours of autonomy can reduce the COE of the system which can deliver the peak loads of the system.
10. A. Maleki, A. Askarzadeh, Sol. Energy 107, 227 (2014).

11. T. Ma, H. Yang, L. Lu, J. Peng, Renew. Energy 69, 7 (2014).

12. T. Zhou, W. Sun, IEEE Trans. Sustain. Energy 5, 408 (2014).

13. W.C. de Carvalho, R.P. Bataglioli, R.A. Fernandes, D.V Coury, Electric Power Syst. Res. 184, 106287 (2020).

14. S.A. N'guessan, K.S. Agbli, S. Fofana, D. Hissel, Int. J. Hydrogen Energy 45 No 8, 5512 (2020).

15. H. Shayeghi, F. Monfaredi, A. Dejamkhooy, M. Shafie-khah, J.P.S. Catalão, Int. J. Electr. Pow. Energy Syst. 125, 106391 (2020).

16. G.L. Park, A.I. Schäfer, B.S. Richards, Renew. Energy 50, 126 (2013).

17. Y. Yuan, C. Sun, M. Li, Q. Li, Electr. Pow. Syst Res. 127, $323(2015)$ 


\title{
Оптимізація, чутливість та енергоменеджмент гібридних систем відновлюваної енергії для кліматичних умов Haldia за допомогою програмного забезпечення HOMER: Тематичне дослідження
}

\author{
M. Das ${ }^{1}$, R. Mandal ${ }^{2}$ \\ 1 AEIE Department, Haldia Institute of Technology, Haldia, India \\ ${ }^{2}$ School of Energy Studies, Jadavpur University, Kolkata, India
}

\begin{abstract}
В теперішній час зростає попит на гібридні системи відновлюваної енергії (HRES) для обслуговування різних типів навантажень. Джерела фотоелектричної енергії та енергії вітру доповнюють одне одного. HRES з використанням джерел фотоелектричної енергії та енергії вітру може підвищити надійність системи для обслуговування навантаження протягом року. У роботі аналізуеться вартість, доцільність використання та надійність двох типів HRES з використанням програмного забезпечення HOMER для місцевості Haldia (Індія), а саме гібридної системи фотоелектрична енергія/ енергія вітру/акумулятор та гібридної системи фотоелектрична енергія/енергія вітру/суперконденсатор. Ці системи оптимізовані за вартістю з використанням чистої приведеної вартості (NPC) системи і вартості енергії (COE) системи. Сонячне випромінювання, швидкість вітру, температура ділянки місцевості, погодинне навантаження та вартість одиниці компонентів HRES вводяться в програмне забезпечення HOMER. Доцільність використання системи вивчаеться за найменшої COE з різними співвідношеннями виробництва електроенергії від фотоелектричних та вітроенергетичних систем. Надій ність системи вимірюеться у відсотках незадоволеного навантаження. Встановлено, що частки виробництва фотоелектричної та вітрової енергії 80:20 та 73:27 е оптимальними відповідно для систем фотоелектрична енергія/енергія вітру/акумулятор та фотоелектрична енергія/енергія вітру/суперконденсатор для кліматичних умов місцевості Haldia. Аналіз чутливості до технічних параметрів і витрат, а також енергоменеджмент системи представлено в роботі. Дослідження показало, що HRES з суперконденсатором може забезпечити пікове навантаження вдень і вночі порівняно з HRES із акумулятором. Воно також виявило, що суперконденсатор може заряджатися дуже швидко з низькими значеннями доступної сонячної або вітрової енергії на відміну від акумулятора.
\end{abstract}

Ключові слова: PV, Вітер, Акумулятор, Суперконденсатор, Гібридний, HOMER. 